\title{
Amperometric tape ion sensors for cadmium(II) ion analysis
}

\author{
Hye Jin Lee $^{\mathrm{a}, *}$, Grégoire Lagger ${ }^{\mathrm{b}}$, Carlos M. Pereira ${ }^{\mathrm{c}}$, Antonio F. Silva ${ }^{\mathrm{c}}$, Hubert H. Girault ${ }^{\mathrm{b}}$ \\ a Department of Chemistry, Kyungpook National University, 1370 Sankyuk-dong, Buk-gu, Daegu 702-701, Republic of Korea \\ b Laboratoire d'Electrochimie Physique et Analytique, Station 6, Ecole Polytechnique Fédérale de Lausanne, CH-1015 Lausanne, Switzerland \\ c Centro de Investigação em Química-L4, Departamento de Química, Faculdade de Ciências da Universidade do Porto, P-4169-007 Porto, Portugal
}

\section{A R T I C L E I N F O}

\section{Article history:}

Received 27 August 2008

Received in revised form 23 October 2008

Accepted 24 October 2008

Available online 11 November 2008

\section{Keywords}

Cadmium ion

ETH 1062 ligand

Complexation

ITIES

Liquid | gel interface

Ionode

Assisted ion transfer

\begin{abstract}
A B S T R A C T
This paper describes a novel tape platform ion sensing methodology specific to the detection of cadmium(II) ions in aqueous solution based on assisted ion transfer reactions across a polarized water|organic gel micro-interface. The tape ion sensors were constructed to incorporate the microwater | polyvinylchloride-2-nitrophenylethyl ether (PVC-NPOE) gel interfaces referred to as ionodes. The sensors have overall thicknesses less than $300 \mu \mathrm{m}$, allowing their packaging in a disposable tape format. The detection methodology is based on the selective assisted transfer of the cadmium ion in aqueous phase by ETH 1062 present in the PVC-NPOE gel layer and was first investigated using cyclic voltammetry. Quantitative analysis of cadmium(II) ions in aqueous solution using the tape sensors was then conducted under stop-flow conditions. Detection limits as low as $20 \mathrm{ppb}(178 \mathrm{nM})$ for Cd(II) ions in very small volumes as low as a single $20 \mu \mathrm{l}$ droplet without any sample preconcentration was achieved in an analysis time of approximately $20 \mathrm{~s}$, which could be easily employed for the direct measurement of $\mathrm{Cd}(\mathrm{II})$ ion levels in various field applications. The tape ion sensor can also be used in a flow-cell geometry to preconcentrate $\mathrm{Cd}(\mathrm{II})$ ions from aqueous samples and further improve the detection limit.
\end{abstract}

(c) 2008 Elsevier B.V. All rights reserved.

\section{Introduction}

Amperometric ion selective electrodes (ISE) have been powerfully employed in the sensing of a wide range of ionic species [1-6]. The most common approach is to utilize solidified polymeric membranes composed of a plasticizer and an ion carrier (ionophore or ligand), which selectively complexes to a target ion [7-9]. The same design principle can be applied to construct an amperometric ion sensor to monitor ion transfer reactions at the interface between two immiscible liquids where one of the phases, typically being the organic phase, is gelified [10-17]. This approach has been successfully demonstrated by several authors during the last decade, mainly using a nitrobenzene gel as the organic phase for the direct and assisted ion transfer, in a stagnant aqueous solution or combined with flow systems [18-22]. Due to the increasing concern with environmental issues, the organic phase must have a reduced toxicity and a long-term stability as well as maintaining good electrochemical characteristics. $O$-Nitrophenyloctylether (NPOE) together with polyvinylchloride (PVC) as a gelifying agent fulfils these criteria and can be printed at a temperature above its sol-gel transition (hot casting method)

\footnotetext{
* Corresponding author. Tel.: +82 53950 5336; fax: +82 539506330 . E-mail address: hyejinlee@knu.ac.kr (H.J. Lee).
}

$[23,24]$. This water | PVC-NPOE gel interface has been implemented into an array of microholes using a standard cell arrangement for studying the selective transfer of alkali metal ions and anions from the aqueous to the organic phase via direct and assisted transfer reactions [25-27].

The ion transfer reaction across the polarized water|organic gel interface can ideally be employed for the selective and sensitive detection of heavy metal ionic species. For example, Katano and Senda [28] have shown that the low ppb detection limit can be attained by stripping voltammetry of heavy-metal ions across a water $\mid$ gel interface. Electrochemical extraction of large ionic concentrations with the use of micro-machined supported liquid membranes has also been reported, particularly for lead extraction from a lead/zinc solution [29]. In this paper, we demonstrate a novel disposable tape ion sensor utilizing the assisted transfer reaction of $\mathrm{Cd}^{2+}$ ions by ETH 1062 across the micro-interface of water | PVC-NPOE gel. The thin strip tape ion sensor was fabricated using a combination of laser micro-machining and screen-printing techniques. A cyclic voltammetry was used to characterize the electrochemical response of $\mathrm{Cd}^{2+}$ ion transfer by ETH 1062 at the interfaces. As a first demonstration, the quantitative analysis of cadmium(II) ions using the tape sensors was conducted under stopflow condition with a small aqueous sample volume (about $20 \mu \mathrm{l}$ ) as well as under continuous flow conditions for achieving a higher preconcentration effect. 
(a)(1)

Mylar $12 \mu \mathrm{m}$

$\mathrm{Ag} / \mathrm{Ag} \mathrm{C} 1$ screen printed (RE2)

(2)

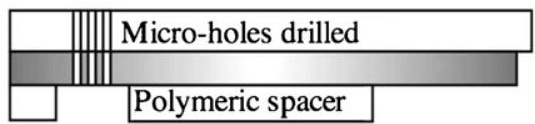

(3)

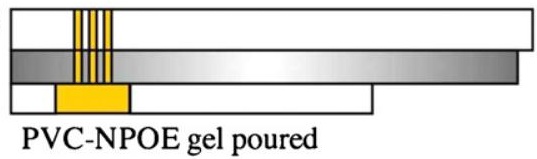

$\mathrm{Ag} / \mathrm{AgCl}$ wire (RE1)

(4)

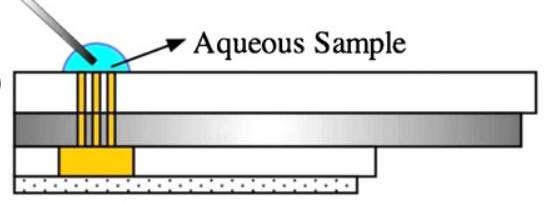

(b)

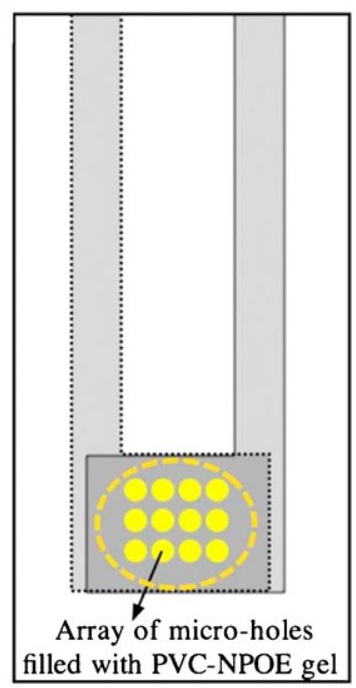

Lamination

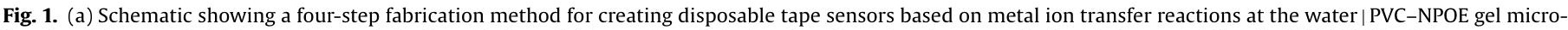
interface. The overall thickness of the strip is about $300 \mu \mathrm{m}$. (b) A top view of the interface featuring the array of micro-holes containing the PVC-NPOE gel.

\section{Experimental}

\subsection{Chemicals}

ETH 1062 (Fluka), polyvinylchloride (PVC, high molecular weight, Sigma), o-nitrophenyloctylether (NPOE, Fluka), $\mathrm{CdCl}_{2}$ (Fluka $>96 \%$ ) and $\mathrm{LiCl}$ (Fluka $>99 \%$ ) were all used as received. The supporting electrolytes for the organic phase was bis(triphenylphosphoranylidene) ammonium tetrakis(4-chlorophenyl)borate (BTPPATPBCl) or tetrabutylammonium tetrakis(4-chlorophenyl)borate (TBATPBCl) prepared as described in a previous paper [23,30]. Most of the cases, $10 \mathrm{mM}$ BTPPATPBCl were used unless otherwise specified. Millipore-filtered water was used for preparing all aqueous solutions.

\subsection{Fabrication of thin tape sensor}

To fabricate the tape sensors, a supporting film of polyethylene terephthalate (12 $\mu \mathrm{m}$ thick, Melinex type "S", ICI Films) supplied on a reel was first cut into strips $(30 \mathrm{~cm}$ long). After cleaning with ethanol, a silver/silver chloride ink (RE 2) was screen-printed as illustrated in Fig. 1a and cured at $80^{\circ} \mathrm{C}$ for $24 \mathrm{~h}$. In a second step, an array of 66 microholes $(11 \times 6)$ was drilled through the film using a UV Excimer laser (ArF, $193 \mathrm{~nm}$, Spectra-Physics). The process of laser micro-machining of the polyester film was performed as described previously [24], but the differences here were the number of laser pulses used to drill through the metallised film and the silver layer being placed at the bottom. The entrance diameter of the microholes is $20 \mu \mathrm{m}$ and the exit $13 \mu \mathrm{m}$ due to the optics used to focus the laser beam so as to drill through the metallic ink layer. After drilling, an adhesive tape that had been punched with a circular aperture was placed on the silver/silver chloride layer. This microfabricated structure acts as a supporting film to deposit the gelified NPOE phase containing PVC. The gel layer was prepared by dissolving PVC $(2.8 \% \mathrm{~m} / \mathrm{m})$ in a solution of $10 \mathrm{mM} \mathrm{BTPPATPBCl}$ or TBATPBCl and ETH 1062 in NPOE, at a temperature of approximately $120^{\circ} \mathrm{C}$. Five microliters of the hot PVC-NPOE liquid at around $80^{\circ} \mathrm{C}$ was manually casted on the arrays via the aperture in the adhesive film. Finally, the casted PVC-NPOE solution was allowed to cool for a minimum of $6 \mathrm{~h}$ to form the gel followed by laminating the underside of the tape with a polyethylene (PE)-polyethylene terephthalate (PET) film ( $35 \mu \mathrm{m}$ thick). In the present work, the screen-printing of $\mathrm{Ag} / \mathrm{AgCl}$ ink was carried out after cutting the tape into sections adapted to the size of the screen used $(30 \mathrm{~cm} \times 30 \mathrm{~cm})$. The strip sensor was employed in two different ways for the amperometric measurements of small volumes of $\mathrm{Cd}^{2+}$ ions; (i) simply placing a drop of aqueous solution containing $\mathrm{Cd}^{2+}$ ions onto the sensing part, with the aqueous reference electrode dipped in the drop (see Fig. 1a), and (ii) placing the sensor in the flow cell prototype (see also Fig. 5). All the processes used here i.e. screen printing of $\mathrm{Ag} / \mathrm{AgCl}$ ink, laser ablation, adhesion of a spacer film and lamination could be mounted in a continuous reel-to-reel assembly line for high-throughput industrial production of the tape.

\subsection{Electrochemical measurements}

The electrochemical experiments were performed using a computer controlled potentiostat (Sycopel Scientific Ltd.) with the data acquired without IR drop compensation. Half-wave potential measurements for ion transfer reactions are referred to $\mathrm{Ag} / \mathrm{AgCl}\left(c_{\mathrm{Cl}^{-}}=\right.$ $0.01 \mathrm{M}$ ) unless otherwise stated. The interfacial ion transfer and ion-ligand complexation processes across the water|PVC-NPOE fabricated in a tape platform sensor were studied by cyclic voltammetry using Cell I.

Cell I:

$\underbrace{\mathrm{AgCl} \mid \mathrm{Ag}}_{\text {Pseudo RE2 }} \begin{array}{ll}\begin{array}{l}2.8 \% \mathrm{PVC}-\mathrm{NPOE} \\ 10 \mathrm{mM} \text { BTPPATPBCl } \\ +10 \mathrm{mM} \text { ETH 1062 }\end{array} & \begin{array}{l}y \mathrm{mMCdCl}_{2} \\ \underbrace{10 \mathrm{mM} \mathrm{LiCl}}_{\text {Polymer membrane }}\end{array}\end{array}$

Ion transfer reactions across micro-interfaces which involve small currents (in all cases here, lower than $100 \mathrm{nA}$ ), only two reference electrodes are necessary, each one acting as both the reference and counter for the aqueous and organic phase. The aqueous phase reference electrode was made of silver/silver chloride in equilibrium with a chloride aqueous solution (RE 1 ). For the organic phase reference system, a pseudo-reference electrode (screen printed $\mathrm{Ag} / \mathrm{AgCl}, \mathrm{RE} 2$ ) was utilized where the $\mathrm{Ag} / \mathrm{AgCl}$ was 
directly in contact with PVC-NPOE gel in the absence of organic supporting electrolyte. This was essential to conveniently assemble it to the tape sensing platform. On the other hand, for the case of Fig. 3 where we used a conventional micro-water/PVC-NPOE gel configuration, the cyclic voltammogram for the $\mathrm{Cd}(\mathrm{II})$ ion transfer was obtained using the TBA ${ }^{+}$ISE organic reference system and Cell II. TBA ${ }^{+}$Ion selective electrodes $\left(\mathrm{TBA}^{+} \mathrm{ISE}\right)$ were composed of a $\mathrm{Ag} / \mathrm{AgCl}$ reference electrode in contact with the organic supporting electrolyte solution (e.g. $10 \mathrm{mM} \mathrm{TBACl}$ ).

Cell II:

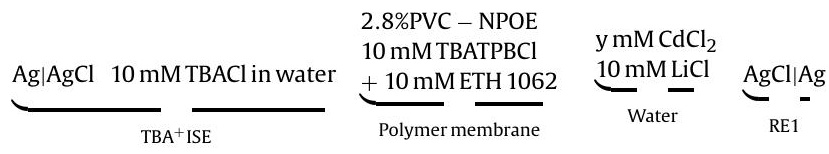

The electrochemical set-up used here was similar to that for the study of alkali metal ion transfer reactions across microwater | PVC-NPOE gel interface as described previously [23]. Briefly, two reference electrodes for both the aqueous and organic phases were made of silver/silver chloride in equilibrium with a chloride aqueous solution; for the organic phase, a TBA ${ }^{+}$ISE reference system was used. The water $\mid$ organic gel interface was formed by water phase containing $\mathrm{CdCl}_{2}$ in contact with micro-fabricated membranes featuring 66 microholes in a $12 \mu \mathrm{m}$ thick PET film filled up with PVC-NPOE gel as described above.

\section{Results and discussion}

Measurements of $\mathrm{Cd}^{2+}$ ion concentrations are very important since overexposure is extremely dangerous to public health and our ecology. Consequently, all countries in the world have established regulations on permissible concentrations of $\mathrm{Cd}^{2+}$ ions. For example, guidelines supplied world health organization [31], suggest an upper cadmium ion concentration of $3 \mathrm{ppb}(26.7 \mathrm{nM})$ in drinking water. Also, the US Environmental Protection Agency set the permissible $\mathrm{Cd}$ ion concentrations in water as $10 \mathrm{ppb}(89 \mathrm{nM})$ [32]. More details on allowed levels of cadmium in various environments can also be found from [33]. A disposable sensor that is easy to use, reliable, free of toxic elements as well as inexpensive to fabricate can be powerfully used for trace cadmium metal ion analysis. We have designed a disposable thin strip type ion sensor featuring micro-water $\mid$ gel interfaces (see Fig. 1a) that utilizes very small sample volumes below $20 \mu \mathrm{l}$. Additional advantages of this sensor include: (i) the sensor packaging can be promptly achieved using a simple printing procedure, and (ii) the sensor strips can be placed on a dispenser such as a tape and consequently used under a flow system.

The electrochemical response of the thin strip sensor associated with the interfacial transfer of cadmium(II) ions facilitated by the ligand, ETH 1062, present in the PVC-NPOE gel layer was first characterized. A series of cyclic voltammograms obtained using Cell I for various cadmium ion concentrations are displayed in Fig. 2a. A small aqueous solution with a volume of about $20 \mu$ l containing various concentrations of cadmium(II) ions ranging from 1 to $100 \mu \mathrm{M}$ and $10 \mathrm{mM}$ of ETH 1062 were used. The transfer of $\mathrm{Cd}^{2+}$ ions can be clearly seen within the potential window limited by the transfer of $\mathrm{Cl}^{-}$ion at the negative end potential and the transfer of $\mathrm{Li}^{+}$ion at the positive end potential. The steady-state current observed on the forward scan linearly increased as the cadmium concentration increased when the ligand concentration $(10 \mathrm{mM})$ is in excess (see Fig. 2b). This indicates that the sensing method involving excess ligand concentrations compared to the metal analytes can be usefully employed for the quantitative analysis of $\mathrm{Cd}^{2+}$ ions in aqueous samples. However, above $40 \mu \mathrm{M}$ concentrations of $\mathrm{Cd}^{2+}$ ions, the steady state current no longer increases and the top
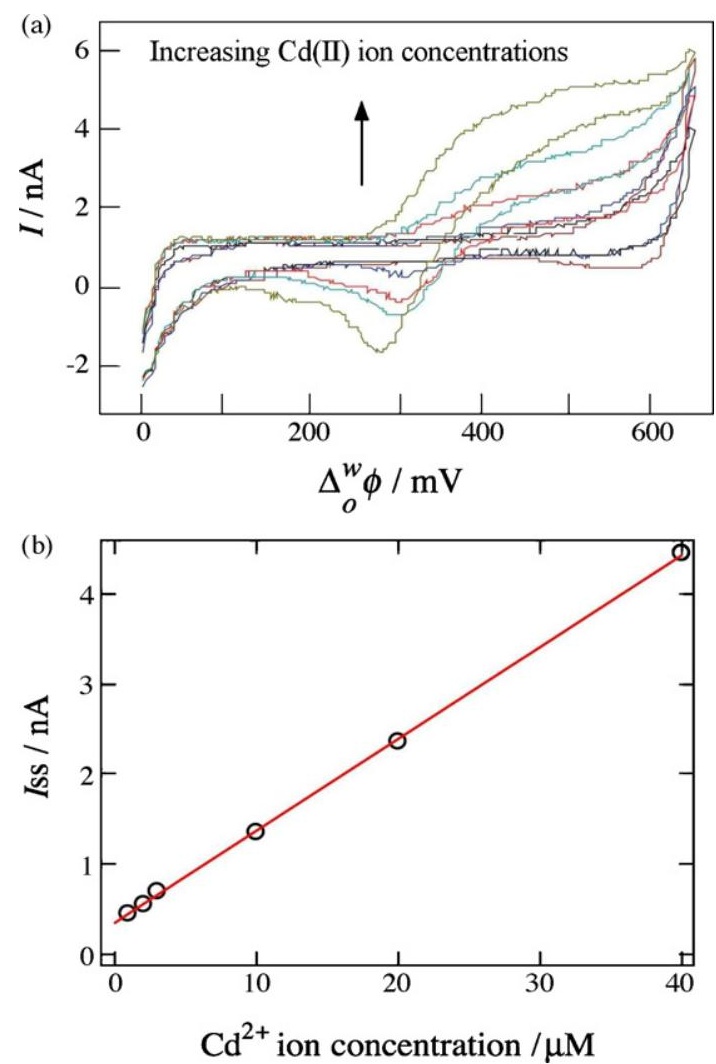

Fig. 2. (a) A series of cyclic voltammograms obtained for the assisted transfer of various concentrations of $\mathrm{Cd}^{2+}$ ions by $10 \mathrm{mM}$ ETH 1062 in the PVC-NPOE gel across the water | gel interface using the strip sensor. The aqueous phase contains $10 \mathrm{mM}$ $\mathrm{LiCl}$ and the PVC-NPOE gel phase contains $10 \mathrm{mM} \mathrm{BTPPATPBCl}$ as a supporting electrolyte respectively. Cell I was used and $\mathrm{Cd}^{2+}$ ion concentrations were $1,2,5,20$, 40 and $100 \mu \mathrm{M}$. Scan rate was $10 \mathrm{mV} \mathrm{s}^{-1}$. (b) Plot of steady-state currents for the assisted transfer of $\mathrm{Cd}^{2+}$ by ETH $1062(10 \mathrm{mM})$ as a function of $\mathrm{Cd}^{2+}$ ion concentrations (calibration curve in the excess ligand case). Some of the data are taken from (a).

curve in Fig. 2a shows two transferring waves for a $100 \mu \mathrm{M}$ concentration of $\mathrm{Cd}^{2+}$ ions on the forward scan. In this region where no clear excess is present from any of the species due to the slow diffusion of the ligand in the gel, a second peak at a more positive potential occurs which can be assigned as the formation of the $1: 1$ complex [Cd-ETH 1062] ${ }^{2+}$. On the reverse scan, a peak shape of signal was observed mainly due to the fact that the [Cd-ETH 1062] complex formed during the forward scan is diffusing along the hole, up to the interface where the ion is released. When using the hole length is $12 \mu \mathrm{m}$ (thickness of the PET film), a major part of the complex previously formed is diffusing towards the bulk of the gel even when the potential across the interface allows the transfer back of the metal ion in the aqueous phase [34]. This has the main effect of limiting the possibility of ionic preconcentration in the gel. In an analytical point of view, a compromise must be found between small micro-holes with smaller IR drop and larger ones with higher preconcentration effect but also increased IR drop [24]. It should be noted that the data presented in Fig. 2 appears to be slightly noisy mainly due to the fact that the measured current associated with both the low concentration of $\mathrm{Cd}^{2+}$ ions and the small interface is as low as below $\sim 1 \mathrm{nA}$. In addition, some instability issues may arise from the use of the pseudo-organic reference electrode where the $\mathrm{Ag} / \mathrm{AgCl}$ layer is directly in contact with the PVC-NPOE gel. Nevertheless, the pseudo-electrode behaves similarly to the organic $\mathrm{Ag} / \mathrm{AgCl}$ reference electrode which is referenced with the organic supporting electrolyte such as TBACl solution (TBA ${ }^{+} \mathrm{ISE}$ ) (see also Fig. 3). The successful application with the pseudo-electrode also 


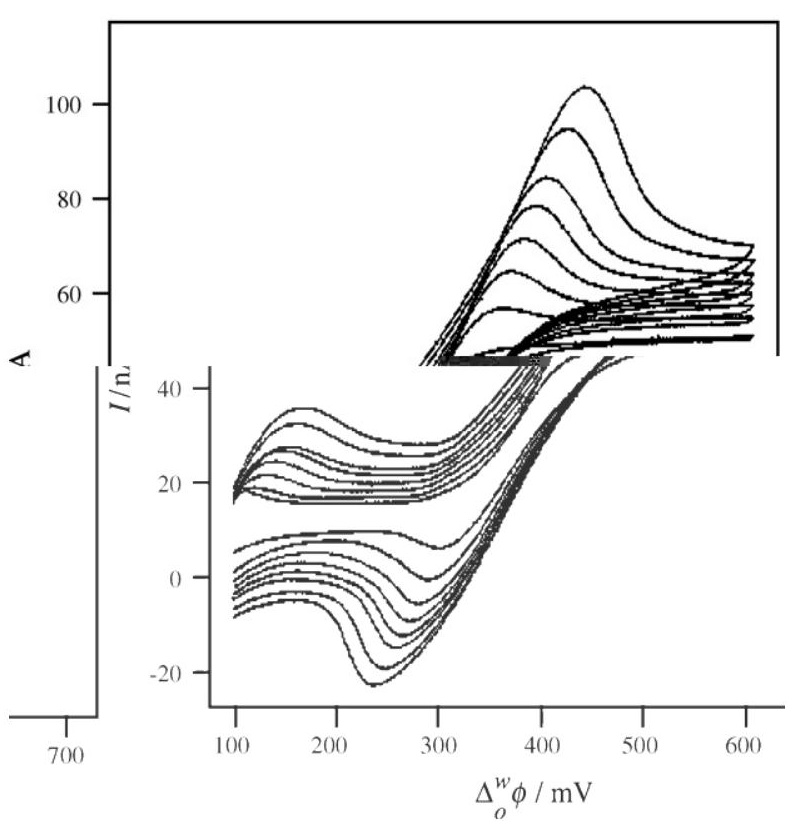

Fig. 3. Cyclic voltammograms obtained for the assisted transfer reaction of $\mathrm{Cd}^{2+}$ ions by the ligand ETH 1062 at various scan rates using Cell II. The concentrations used for $\mathrm{Cd}^{2+}$ ions and ETH 1062 were $120 \mathrm{mM}$ and $10 \mathrm{mM}$, respectively. Scan rates were $5,10,15,20,25,30,40$ and $50 \mathrm{mV} \mathrm{s}^{-1} .10 \mathrm{mM}$ TBATPBCl was used as an organic supporting electrolyte. The IR drop is estimated here to be $200 \mathrm{M} \Omega$.

makes the tape sensor more convenient to fabricate and easy to utilize in field applications.

Further studies elucidating the peak shape of the ion transfer reaction were performed when the $\mathrm{Cd}^{2+}$ ion concentration is in excess compared to the ligand ETH 1062 concentration. Fig. 3 shows a series of cyclic voltammograms obtained at different scan rates using the organic reference electrode with $\mathrm{Ag} / \mathrm{AgCl}$ in contact with the organic supporting electrolyte such as $\mathrm{TBACl}$ solution and $10 \mathrm{mM}$ TBATPBCl in the PVC-NPOE gel. For short periods of time (higher scan rates above $50 \mathrm{mV} \mathrm{s}^{-1}$ ), a strong peak shape voltammogram on the forward scan was observed because the ligand depletion region stays within the hole owing to much lower diffusion coefficients of the ligand in the gel compared to that of the metal ions in the aqueous phase. When the scan rate is of the order of $50 \mathrm{mV} \mathrm{s}^{-1}$ or lower, the two successive regimes of ligand diffusion are visible in the peak shapes (peak, then steady-state). At very low scan rates (below $10 \mathrm{mV} \mathrm{s}^{-1}$ ), the linear diffusion behavior is becoming insignificant and the diffusion is mainly spherical over the forward scan period. At the potential of the transition point between linear and spherical diffusions, it is possible to estimate the diffusion coefficient of the ligand in the gel, knowing the micro-hole length ( $12 \mu \mathrm{m}$ long in this experiment), which is calculated to be $3 \times 10^{-11} \mathrm{~m}^{2} \mathrm{~s}^{-1}$. This diffusion coefficient is in relatively good agreement with the values estimated for similar systems in a previous paper [23].

Following the well-defined electrochemical behaviour of $\mathrm{Cd}^{2+}$ ion transfer process at the interface of thin strip sensor platforms, we have further employed the strip sensor for the quantitative analysis of $\mathrm{Cd}^{2+}$ ion concentration in aqueous sample. Differential pulse stripping voltammetry was applied for $\mathrm{Cd}^{2+}$ concentrations ranging from 0 to $391 \mathrm{nM}(44 \mathrm{ppb})$ when the ligand ETH $1062(10 \mathrm{mM})$ is in excess. Fig. 4 demonstrates a series of differential pulse stripping voltammograms acquired for aqueous drops $(20 \mu \mathrm{l})$ in the absence of $\mathrm{Cd}^{2+}$ ions, and also $\mathrm{Cd}^{2+}$ ions at concentrations of $196 \mathrm{nM}$ and $391 \mathrm{nM}$. These were obtained without any preconcentration (plating) of $\mathrm{Cd}^{2+}$ ions. For comparison, the very top voltammogram in Fig. 4 was obtained at a $\mathrm{Cd}^{2+}$ ion concentration of $391 \mathrm{nM}$ after a

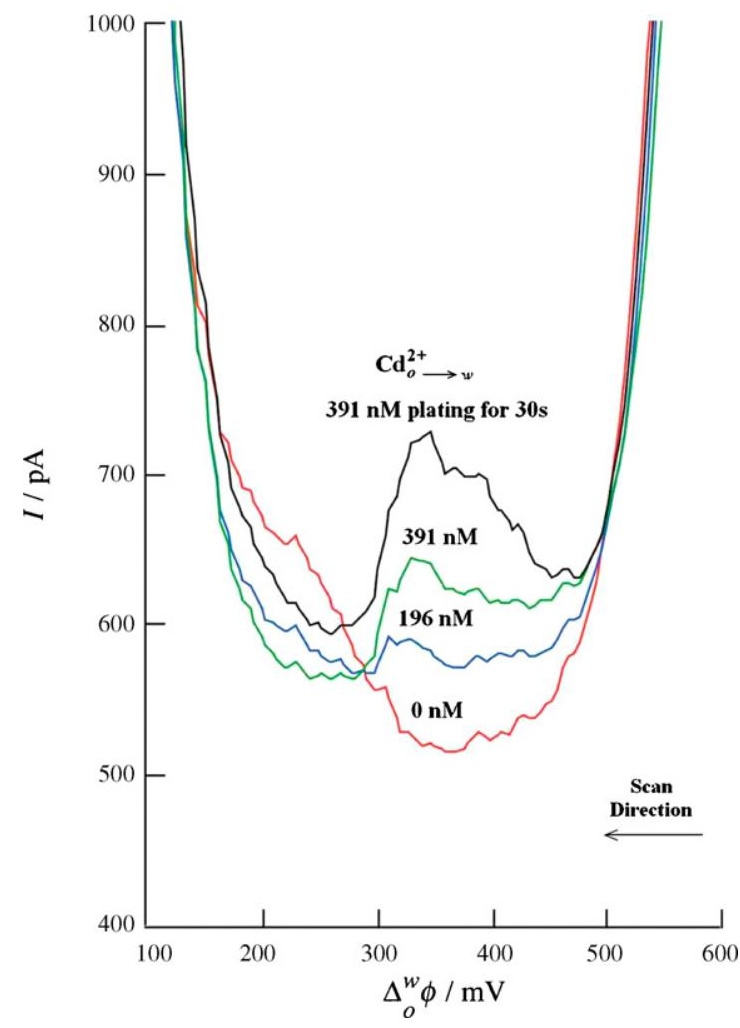

Fig. 4. Differential pulse stripping voltammograms of $\mathrm{Cd}^{2+}$ ion transfer from the gel, after the assisted transfer by ETH $1062(10 \mathrm{mM})$. The pulse conditions were potential increment of $2 \mathrm{mV}$, pulse potential of $10 \mathrm{mV}$ and pulse duration of $50 \mathrm{~ms}$ (scan rate is $20 \mathrm{mV} \mathrm{s}^{-1}$ ). The scan was directed from high to low potentials to drive $\mathrm{Cd}^{2+}$ ion transfer from the organic to aqueous phase. From bottom to top: curve obtained without any cadmium ions, with $196 \mathrm{nM}$ of $\mathrm{Cd}^{2+}$ ions in water, followed by $391 \mathrm{nM}$ without any preconcentration (plating) of $\mathrm{Cd}^{2+}$ ions. The top voltammogram was obtained after a preconcentration step for $391 \mathrm{nM} \mathrm{Cd}^{2+}$ ions in water by applying the potential at $600 \mathrm{mV}$ for $30 \mathrm{~s}$ prior to analysis.

preconcentration step by applying a potential of $600 \mathrm{mV}$ for $30 \mathrm{~s}$ prior to analysis. It can be clearly seen that the preconcentration process enhances the detection signal by approximately a factor of two compared to that obtained without any preconcentration step. All these signals represent the extraction of the $\mathrm{Cd}^{2+}$ ions from the organic gel (where they are complexed by the ligand), back to the aqueous phase. The detection limit was found to be about $178 \mathrm{nM}(20 \mathrm{ppb})$ of $\mathrm{Cd}^{2+}$ ions in a $20 \mu$ l volume assay (about $4 \mathrm{pmol}$ ), allowing the direct application of the sensor to determine $\mathrm{Cd}^{2+}$ ion levels in various environmental samples. The sensitivity of the ion tape sensor is better than commercially available ionselective electrodes (e.g. $890 \mathrm{nM}(100 \mathrm{ppb})$ of $\mathrm{Cd}^{2+}$ ions) [35] and comparable to conventional atomic absorption spectrometry (AAS) and inductively coupled plasma (ICP) atomic emission spectrometry [36]. Nevertheless, the ion sensor has a distinct advantage in requiring smaller sample volumes with additional possibilities for multiplexed and selective sensing as well as portability. Typically, AAS or ICP requires a minimum sample loading volume of over $50 \mu$ l. In principle, even smaller volumes of sample drops (below $5 \mu \mathrm{l}$ ) could be applied in the tape sensor, which would still cover the entire micro-hole interface; however, the rate of evaporation of the aqueous sample must be taken into account at such low volumes.

The tape ion sensor was finally integrated into a flow system (Metrohm flow cell prototype) to achieve a higher preconcentration of $\mathrm{Cd}^{2+}$ ions in the gel layer under a continuous solution flow (see Fig. 5). A representative differential pulse voltammogram of $1 \mu \mathrm{M} \mathrm{Cd}^{2+}$ ion detection is displayed in a right inset of the figure. The assisted transfer of $\mathrm{Cd}^{2+}$ ions by the ligand ETH 1062 across the 


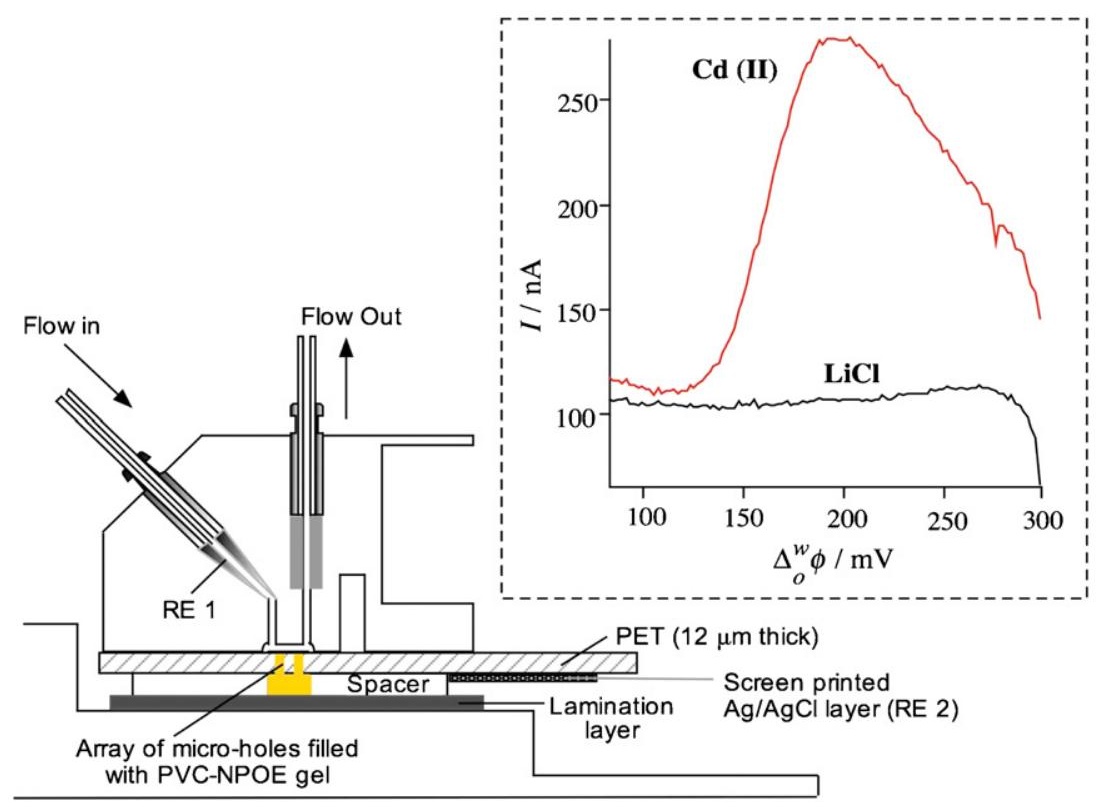

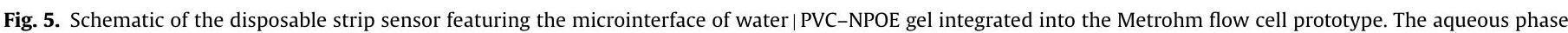

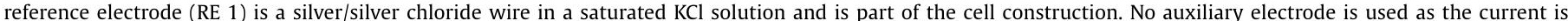

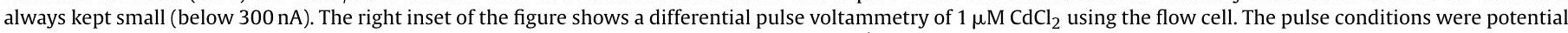
increment of $2 \mathrm{mV}$, pulse potential of $10 \mathrm{mV}$ and pulse duration of $50 \mathrm{~ms}$ (scan rate is $20 \mathrm{mV} \mathrm{s}^{-1}$ ). $10 \mathrm{mM}$ ETH $1062 \mathrm{and}$ flow rate of $1 \mathrm{ml} / \mathrm{min}$ were used.

aqueous/gel interface was clearly observed. Note that a large electrochemical signal for $\mathrm{Cd}^{2+}$ ion sensing was also observed due to the preconcentration of $\mathrm{Cd}^{2+}$ ions in the gel. A practical detection limit based on signal to noise ratio of 3:1 is set here at approximately $100 \mathrm{nM}$ when using the flow cell geometry, which could be even further improved by a better handling of fluid flow. In the present configuration of the pumping system a large electrical noise is generated, which results in reducing the signal to noise ratio.

\section{Conclusions}

A novel disposable tape sensor for the sensitive detection of cadmium ions has been demonstrated. The detection method is based on the assisted transfer reaction of $\mathrm{Cd}^{2+}$ ion by the ligand, ETH 1062 across a water|PVC-NPOE gel microinterface. This sensor can be utilized not only in a stagnant mode but also under analyte flow systems with a simple pseudo-reference electrode system. The total thickness of the sensor typically $300 \mu \mathrm{m}$ allows its packaging in a dispensing tape shape, which could be incorporated into a continuous reel-to-reel assembly line for industrial production of the tape. Detection limits as low as $20 \mathrm{ppb}(178 \mathrm{nM})$ for $\mathrm{Cd}^{2+}$ ions in a stagnant aqueous solution volume of about $20 \mu \mathrm{l}$ for the tape sensor have been achieved within $20 \mathrm{~s}$ of analysis time without preconcentration processes. Further improvements in the integration of the continuous flow aspect of the sensors to preconcentrate $\mathrm{Cd}^{2+}$ ions from aqueous samples as well as applications to the real sample analysis are currently underway.

\section{Acknowledgement}

This work was supported by the Korea Research Foundation Grant funded by the Korean Government (KRF-2008-331-C00190).

\section{References}

[1] B.K. Jena, C.R. Raj, Talanta 76 (2008) 161.
[2] N.H. Chou, J.C. Chou, T.P. Sun, S.K. Hsiung, Sens. Actuators B 130 (2008) 359 .

[3] E. Pretsch, Trends. Anal. Chem. 26 (2007) 46

[4] L. Nagy, M. Kálmán, G. Nagy, J. Biochem. Biophys. Methods 69 (2006) 133.

[5] F. Faridbod, M.R. Ganjali, R. Dinarvand, P. Norouzi, Sensors 8 (2008) 2331.

[6] R. Long, E. Bakker, Electroanalysis 15 (2003) 1261

[7] E. Bakker, Y. Qin, Anal. Chem. 78 (2006) 3955.

[8] E. Bakker, P. Bühlmann, E. Pretsch, Talanta 63 (2004) 3.

[9] E. Bakker, E. Pretsch, Anal. Chem. 74 (2002) 420A.

[10] J.A. Ortuno, A. Gil, C. Sanchez-Pedreno, Sens. Actuators B 122 (2007) 369.

[11] J.A. Ortuno, I.C. Sanchez-Pedreno, A. Gil, Anal. Chim. Acta 554 (2005) 172

[12] Z. Samec, E. Samcová, H.H. Girault, Talanta 63 (2004) 21.

[13] T. Osakai, H. Katano, Bunseki Kagaku 54 (2005) 251.

[14] L. Lasse Murtomaki, M.H. Barker, J.A. Manzanares, K. Kontturi, J. Electroanal. Chem. 560 (2003) 95.

[15] Y. Tong, P. Sun, Z. Zhang, Y. Shao, J. Electroanal. Chem. 504 (2001) 52.

[16] H. Katano, M. Senda, Anal. Sci. 17 (2001) i337.

[17] V. Marecek, H. Janchenova, M. Brezina, M. Betti, Anal. Chim. Acta 244 (1991) 15.

[18] H. Katano, M. Senda, J. Electroanal. Chem. 496 (2001) 103.

[19] S. Wilke, H. Franzke, H. Mueller, Anal. Chim. Acta 268 (1992) 285.

[20] T. Osakai, T. Nuno, Y. Yamamoto, A. Saito, M. Senda, Bunseki Kagaku 38 (1989) 479.

[21] E. Wang, H. Ji, Electroanalysis 1 (1989) 75.

[22] V. Marecek, M.P. Colombini, J. Electroanal. Chem. 241 (1988) 133.

[23] H.J. Lee, C. Beriet, H.H. Girault, J. Electroanal. Chem. 453 (1998) 211

[24] H.J. Lee, P.D. Beattie, B.J. Seddon, M.D. Osborne, H.H. Girault, J. Electroanal. Chem. 440 (1997) 73.

[25] F. Bianchi, H.J. Lee, H.H. Girault, J. Electroanal. Chem. 523 (2002) 40.

[26] H.J. Lee, C.M. Peirera, A.F. Silva, H.H. Girault, Anal. Chem. 72 (2000) 5562.

[27] H.J. Lee, H.H. Girault, Anal. Chem. 70 (1998) 4280.

[28] H. Katano, M. Senda, Anal. Sci. 14 (1998) 63.

[29] S. Wilke, H.M. Wang, M. Muraczewska, H. Muler, Fresenius J. Anal. Chem. 356 (1996) 233.

[30] Z. Ding, D.J. Fermin, P.F. Brevet, H.H. Girault, J. Electroanal. Chem. 458 (1998) 139.

[31] World Health Organization (WHO/SDE/WSH/03.04/80) Guidelines, World Health Organization, Geneva, 2003.

[32] http://www.inchem.org/documents/pims/chemical/cadmium.html

[33] http://www.cadmium.org/env_lev.html.

[34] J. Josserand, J. Morandini, H.J. Lee, R. Ferrigno, H.H. Girault, J. Electroanal. Chem. 468 (1999) 42.

[35] http://www.astisensor.com/lab_organic.html.

[36] http://www.thermo.com/eThermo/CMA/PDFs/Articles/articlesFile_18407.pdf. 